\title{
Financial Engineering and Financial Performance of Deposit Taking Savings and Credit Co-operative Societies in Kenya.
}

\author{
Kiprotich Charles ${ }^{1}$ and Dr. Onsomu Zipporah ${ }^{2}$
}

\begin{abstract}
The study explores the effect of financial engineering on financial performance of deposit taking Savings and Credit Co-operative Societies (SACCOs) in Kenya. Population constituted of 163 SACCOs and a sample of 45 was considered. The results depicted that SACCOs have adopted financial engineering practices in three forms: product engineering, process engineering and financial solutions engineering. In terms of their effect on performance, only process engineering was found to have a positive and significant relationship with financial performance. Product engineering and financial solutions engineering were found to have a positive but insignificant relationship was obtained. The study recommends that SACCOS should adopt financial engineering practices so as to improve their performance. More focus should be on process engineering. As such, SACCOs should automate their operations, adopt paperless services, use mobile banking services platform, use electronic funds transfer and install ATMs so as to improve their performance. In terms of control variables, the amount of loans were found to positively and significantly influence financial performance. As such, SACCOs should strive to derive products that can increase their level of loans.
\end{abstract}

Keywords: Financial engineering, Financial performance, SACCOs, Kenya.

\footnotetext{
1 Audit Supervisor, Office of the Auditor General, Kenya.

${ }^{2}$ Lecturer, Department of Finance and Accounting, School of Business, University of Nairobi.
}

Article Info: Received: July 16, 2020. Revised: February 2, 2021.

Published online: February 10, 2021. 


\section{Introduction}

Financial engineering means creating non-existing better products and services in finance through innovation with regard to financial instruments (Osuoha, 2013). According to Swailem (2000), it is about designing, developing and implementing tools and innovative financing mechanisms, as well as working out creative solutions to financing problems. According to Ibrahim (2013) it is application of instruments in finance especially derivatives and other closely linked products that helps in the restructuring of cash flows to achieve certain financial objectives including the need to manage risks in finance. The area of application of financial engineering comprises three areas such as innovativeness in securities, improving financial processes and developing solutions to issues in company finance (Sayyed, 2015).

The concept of financial engineering is modelled on various theories which include innovation diffusion theory (Rogers, 1962), constraint-induced financial innovation theory (Silber, 1983) and theory of innovation (Schumpeter, 1934). The innovation diffusion theory provides an explanation on the spread of information about new goods, services and approaches in a given set up. The basis of the theory is that information about new inventions tend to spread overtime as firms adopt them to remain relevant in competition. The implication is that people eventually starts to replace old approaches with the new inventions. According to the theory of innovation, cyclical process experienced in business entirely revolve around innovation as businesses come up with new processes, products and services. It asserts that innovation implies the changes in the methods of production and transportation, production of a new product, change in the industrial organization and opening up of a new market. Lastly, constraint-induced financial innovation theory depicts that financial engineering therefore gives an organization an opportunity to shed off its strategic problems and realign internal operations for improved financial performance. It gives an organization some competitive edge and meet consumer and market demands on an effective basis.

Savings \& Credit Co-operative Societies (SACCOs) face immense competition from conventional banks which limit their operations. As such, they have introduced innovative products such as debit cards, credit cards, ATM cards, M-Pesa and others that facilitate the use of electronic means of payment. This makes them competitive among other actors in the financial markets. The financial innovations have also resulted in financial inclusion among Kenyans who were initially excluded. The increased level of activities attributed to financial engineering may influence performance positively.

\section{Preliminary Notes}

Multiple regression analysis was then used to help in the determination of the relationship between financial engineering and financial performance. Statistical package for social science (SPSS) was used to generate inferential and descriptive statistics. To help in the determination of the effect of financial engineering on 
financial performance, the following regression model was used:

$\mathrm{Y}=\beta_{0}+\beta_{1} \mathrm{X}_{1}+\beta_{2} \mathrm{X}_{2}+\beta_{3} \mathrm{X}_{3}+\beta_{4} \mathrm{X}_{4}+\beta_{5} \mathrm{X}_{5}+\varepsilon$

Where:

$\mathrm{Y}=$ Financial Performance. It is measured as total income.

$\beta_{0}=$ it is the regression constant or intercept

$\beta_{1}, \beta_{2}, \beta_{3}, \beta_{4}=$ Coefficient of Independent variables

$\beta_{4}$ and $\beta_{5}=$ Coefficient of Control Variables

$\mathrm{X}_{1}=$ Product Engineering. This is measured in terms of adoption of new financial products and services.

$\mathrm{X}_{2}=$ Process Engineering. This is measured in terms of the improvement of operational processes.

$\mathrm{X}_{3}=$ Financial Solutions Engineering. This is measured in terms of new ways of solving financial-related problems.

$\mathrm{X}_{4}=$ Total loans (control variable).

$\mathrm{X}_{5}=$ Size of the firm. This is measured as total assets (control variable).

$\varepsilon=$ Error term.

\section{Main Results}

\subsection{Introduction}

Primary data and secondary data were used in the study. Primary data was collected using questionnaires. The respondents were SACCO finance managers of the fortyfive (45) deposit taking SACCOs in Mombasa and Nairobi counties. The response rate was $100 \%$. Secondary data was collected from published information. The study period was 2014 2018. The data was analyzed using SPSS.

\subsection{Descriptive Statistics}

Descriptive statistics was used to describe and compare variables numerically. The arithmetic mean was used as a measure of central tendency and the standard deviation as a measure of the level of dispersion in the distributions. The results for the adoption of financial engineering practices are presented below: 
Table 1: Product Engineering

\begin{tabular}{|l|c|c|c|c|}
\hline \multicolumn{1}{|c|}{ Practice } & N & Mean & $\begin{array}{c}\text { Std. } \\
\text { Deviation }\end{array}$ & Rank \\
\hline $\begin{array}{l}\text { The SACCO has come up with } \\
\text { investment clubs in areas such as } \\
\text { real estate. }\end{array}$ & 45 & 3.9778 & .94120 & 2 \\
\hline $\begin{array}{l}\text { There are investment clubs for } \\
\text { members through registration. }\end{array}$ & 45 & 3.9556 & .82450 & 3 \\
\hline $\begin{array}{l}\text { The SACCOs have credit and Debit } \\
\text { cards for account holders. }\end{array}$ & 45 & 3.9111 & .90006 & 4 \\
\hline There is increased FOSA activities. & 45 & 4.0444 & .82450 & 1 \\
\hline $\begin{array}{l}\text { There is investment in government } \\
\text { bills and bonds. }\end{array}$ & 45 & 3.8667 & .96766 & 5 \\
\hline Valid N (listwise) & $\mathbf{4 5}$ & $\mathbf{3 . 9 5}$ & & \\
\hline
\end{tabular}

Source: Research Data (2019)

Table 1 shows that on average, the SACCOs adopt product engineering practices to a high extent with a mean of 3.95. Specifically, the mostly adopted practice include the increase in FOSA activities, then the existence of investment clubs in real estate followed by the use of credit and debit cards with a mean of 4.0444, 3.9778 and 3.9556 respectively. The SACCOs also invest in government bills and bonds with a mean of 3.8667. The findings imply that from a general perspective the SACCOs adopt product engineering practices. The standard deviations indicate the variations in responses on a particular practice by the respondents.

Table 2: Process Engineering

\begin{tabular}{|l|c|c|c|c|}
\hline \multicolumn{1}{|c|}{ Practice } & N & Mean & $\begin{array}{c}\text { Std. } \\
\text { Deviation }\end{array}$ & Rank \\
\hline $\begin{array}{l}\text { There is automation of SACCO } \\
\text { operations. }\end{array}$ & 45 & 4.0000 & .90453 & 2 \\
\hline $\begin{array}{l}\text { The SACCOs have adopted paperless } \\
\text { services. }\end{array}$ & 45 & 3.9333 & .83666 & 4 \\
\hline $\begin{array}{l}\text { The SACCOs have adopted Mobile } \\
\text { banking platform for customers. }\end{array}$ & 45 & 4.0000 & .79772 & 2 \\
\hline $\begin{array}{l}\text { The SACCOs use Electronic funds } \\
\text { transfer as a mechanism of } \\
\text { facilitating payments. }\end{array}$ & 45 & 3.7556 & .85694 & 5 \\
\hline $\begin{array}{l}\text { The SACCOs have installed ATMs to } \\
\text { facilitate increased access to cash. }\end{array}$ & 45 & 4.0667 & .83666 & 1 \\
\hline Valid N (listwise) & 45 & 3.95 & & \\
\hline
\end{tabular}

Source: Research Data (2019) 
Table 2 indicate the responses regarding adoption of process engineering activities. The findings show that the best adopted practice was the installation of ATMs to facilitate increased access to cash followed by the use of mobile banking platform for customers and the automation of SACCO operations with means of 4.0667 and 4 respectively. The SACCOs also adopted paperless services with the least practice being the use of electronic funds transfer as a mechanism of facilitating payments having a mean of 3.7556. The overall mean is 3.95 implying that SACCOs have adopted process engineering practices to a high extent in improving their financial performance. The standard deviations indicate the variations in responses on a particular practice by the respondents.

Table 3: Financial Solutions Engineering

\begin{tabular}{|l|l|l|l|l|}
\hline Practice & \multicolumn{1}{|c|}{ N } & \multicolumn{1}{|c|}{ Mean } & $\begin{array}{c}\text { Std. } \\
\text { Deviation }\end{array}$ & \multicolumn{1}{|c|}{ Rank } \\
\hline $\begin{array}{l}\text { The SACCO have come up } \\
\text { with new methods of cash } \\
\text { management. }\end{array}$ & 45 & 4.2000 & .89443 & 1 \\
\hline $\begin{array}{l}\text { There is the use of new } \\
\text { approaches in the management } \\
\text { of debts. }\end{array}$ & 45 & 4.1333 & .86865 & 2 \\
\hline $\begin{array}{l}\text { The SACCOs have developed } \\
\text { new investment strategies. }\end{array}$ & 45 & 4.0889 & .94922 & 3 \\
\hline $\begin{array}{l}\text { There is the use of new } \\
\text { approaches in risk } \\
\text { management. }\end{array}$ & 45 & 4.0000 & .76871 & 5 \\
\hline $\begin{array}{l}\text { The SACCO has adopted } \\
\text { enhanced insurance cover } \\
\text { against loan defaults. }\end{array}$ & 45 & 4.0667 & .78044 & 4 \\
\hline Valid N (Listwise) & $\mathbf{4 5}$ & $\mathbf{4 . 1 0}$ & & \\
\hline
\end{tabular}

Source: Research Data (2019)

Table 3 indicate analysis of responses regarding adoption of financial engineering solutions. The findings show that the most adopted financial solutions engineering practice was the new methods of cash management, followed by the use of new approaches in the management of debts and then the new investment strategies having means of 4.2, 4.1333 and 4.0889 respectively. The SACCOs also adopted enhanced insurance cover against loan defaults and the use of new approaches in risk management with means of 4.0667 and 4 respectively. The overall mean of 4.10 indicate that financial solutions engineering practices are adopted to a very high extent by the SACCOs. The implication is that SACCOs practice financial solutions engineering and the standard deviations indicate variations in responses by the respondents. 


\subsection{Correlation Analysis}

Pearson Bivariate correlation coefficient was used to compute the correlation between the dependent variable (Financial Performance) and the independent variables. The relationship is assumed to be linear and the correlation coefficient ranges from -1.0 (perfect negative correlation) to +1.0 (perfect positive correlation) (Sekaran, 2015). The findings are given in the Table 4.

The results show that the financial performance has a positive and significant relationship with total loans, total assets and product engineering. The implication is that when there is increase in total loans, total assets and product engineering practices, then financial performance also increase significantly. There is however positive but not significant relationship between financial performance (total income) income and process engineering and financial solutions engineering.

Table 4: Correlation Matrix

\begin{tabular}{|c|c|c|c|c|c|c|c|}
\hline & & $\begin{array}{c}\text { Total } \\
\text { Income }\end{array}$ & $\begin{array}{r}\text { Total } \\
\text { Loans } \\
\end{array}$ & $\begin{array}{c}\text { Total } \\
\text { Assets } \\
\end{array}$ & $\begin{array}{c}\text { Product } \\
\text { Engineering }\end{array}$ & $\begin{array}{c}\text { Process } \\
\text { Engineering }\end{array}$ & $\begin{array}{l}\text { Financial } \\
\text { Solutions }\end{array}$ \\
\hline \multirow{3}{*}{$\begin{array}{l}\text { Total } \\
\text { Income }\end{array}$} & $\begin{array}{c}\text { Pearson } \\
\text { Correlation }\end{array}$ & 1 & & & & & \\
\hline & Sig. (2-tailed) & & & & & & \\
\hline & $\mathrm{N}$ & 45 & & & & & \\
\hline \multirow{3}{*}{$\begin{array}{l}\text { Total } \\
\text { Loans }\end{array}$} & $\begin{array}{c}\text { Pearson } \\
\text { Correlation }\end{array}$ & $.978^{* * *}$ & 1 & & & & \\
\hline & Sig. (2-tailed) & .000 & & & & & \\
\hline & $\mathrm{N}$ & 45 & 45 & & & & \\
\hline \multirow{3}{*}{$\begin{array}{l}\text { Total } \\
\text { Assets }\end{array}$} & $\begin{array}{c}\text { Pearson } \\
\text { Correlation }\end{array}$ & $.968^{* *}$ & $.992^{* *}$ & 1 & & & \\
\hline & Sig. (2-tailed) & .000 & .000 & & & & \\
\hline & $\mathrm{N}$ & 45 & 45 & 45 & & & \\
\hline \multirow{3}{*}{$\begin{array}{c}\text { Product } \\
\text { Engineering }\end{array}$} & $\begin{array}{c}\text { Pearson } \\
\text { Correlation } \\
\end{array}$ & $.305^{*}$ & 246 & .216 & 1 & & \\
\hline & Sig. (2-tailed) & .044 & .107 & .160 & & & \\
\hline & $\mathrm{N}$ & 45 & 45 & 45 & 45 & & \\
\hline \multirow{3}{*}{$\begin{array}{c}\text { Process } \\
\text { Engineering }\end{array}$} & $\begin{array}{c}\text { Pearson } \\
\text { Correlation }\end{array}$ & $.628^{* * *}$ & $.555^{* *}$ & $.532^{* *}$ & $.508^{* *}$ & 1 & \\
\hline & Sig. (2-tailed) & .000 & .000 & .000 & .000 & & \\
\hline & $\mathrm{N}$ & 45 & 45 & 45 & 45 & 45 & \\
\hline \multirow{3}{*}{$\begin{array}{l}\text { Financial } \\
\text { Solutions }\end{array}$} & $\begin{array}{c}\text { Pearson } \\
\text { Correlation }\end{array}$ & .250 & .256 & .257 & $.357^{*}$ & 107 & 1 \\
\hline & Sig. (2-tailed) & .101 & .093 & .093 & .017 & .488 & \\
\hline & $\mathrm{N}$ & 45 & 45 & 45 & 45 & 45 & 45 \\
\hline
\end{tabular}




\subsection{Regression Analysis}

To assess the suitability of the research model, a regression analysis was conducted. This also helped to predict causal relationship between product engineering, process engineering, financial solutions engineering, total loans and total assets. The results are discussed below:

Table 5: Model Summary

\begin{tabular}{|c|c|c|c|c|}
\hline Model & R & R Square & Adjusted R Square & Std. Error of the Estimate \\
\hline 1 & $.983^{\mathrm{a}}$ & .966 & .962 & .19464 \\
\hline
\end{tabular}

Table 5 shows that the adjusted $\mathrm{R}^{2}=0.962$. This depicts that $96.2 \%$ of variations in financial performance of SACCOs is explained by the changes in financial solutions engineering, process engineering, product engineering and the control variables (total assets and total loans). The $\mathrm{R}=0.983$ indicating a very strong relationship between the variables.

Table 6: Analysis of Variance

\begin{tabular}{|c|c|c|c|c|c|c|}
\hline \multicolumn{2}{|c|}{ Model } & $\begin{array}{c}\text { Sum of } \\
\text { Squares }\end{array}$ & df & $\begin{array}{c}\text { Mean } \\
\text { Square }\end{array}$ & F & Sig. \\
\hline \multirow{4}{*}{1} & Regression & 41.528 & 5 & 8.306 & 219.233 & $.000^{\mathrm{b}}$ \\
\cline { 2 - 7 } & Residual & 1.440 & 38 & .038 & & \\
\cline { 2 - 7 } & Total & 42.967 & 43 & & & \\
\hline
\end{tabular}

The analysis of variance in Table 6 indicates that the model was significant $(\mathrm{p}<0.05)$. The implication is that financial solutions engineering, process engineering, total assets, product engineering and total loans reliably predict financial performance of SACCOs. 
Table 7: Regression Coefficients

\begin{tabular}{|c|c|c|c|c|c|c|c|c|c|c|}
\hline \multirow{2}{*}{ Model } & \multicolumn{2}{|c|}{$\begin{array}{l}\text { Unstandardized } \\
\text { Coefficients }\end{array}$} & \multirow{2}{*}{$\begin{array}{c}\begin{array}{c}\text { Standardized } \\
\text { Coefficients }\end{array} \\
\text { Beta }\end{array}$} & \multirow{2}{*}{$\mathbf{t}$} & \multirow{2}{*}{ Sig. } & \multicolumn{3}{|c|}{ Correlations } & \multicolumn{2}{|c|}{$\begin{array}{l}\text { Collinearity } \\
\text { Statistics }\end{array}$} \\
\hline & B & \begin{tabular}{c|} 
Std. \\
Error
\end{tabular} & & & & $\begin{array}{l}\text { Zero- } \\
\text { order }\end{array}$ & Partial & Part & Tolerance & VIF \\
\hline (Constant) & -1.048 & .407 & & -2.577 & .014 & & & & & \\
\hline $\begin{array}{l}\text { Product } \\
\text { Engineering }\end{array}$ & .060 & .077 & .029 & .772 & .445 & .305 & .124 & .023 & .613 & 1.630 \\
\hline $\begin{array}{l}\text { Process } \\
\text { Engineering }\end{array}$ & .249 & .095 & .108 & 2.615 & .013 & .628 & .390 & .078 & .516 & 1.939 \\
\hline $\begin{array}{l}\text { Financial } \\
\text { Solutions }\end{array}$ & .012 & .071 & .006 & .170 & .866 & .250 & .028 & .005 & .795 & 1.258 \\
\hline Total Loans & .146 & .042 & .844 & 3.470 & .001 & .978 & .490 & .103 & .015 & 67.174 \\
\hline Total Assets & .009 & .031 & .068 & .283 & .779 & .968 & .046 & .008 & .015 & 65.310 \\
\hline
\end{tabular}

Table 7 indicates that process engineering activities had a positive and significant relationship with financial performance. $(\beta=.249, \mathrm{p}<0.05)$. Product engineering and engineering financial solutionsa have a positive but insignificant relationship with financial performance $(p>0.05)$. In terms of control variables, the amount of loans is positively and significantly related with financial performance $(p<0.05)$. However, total assets have a positive but insignificant relationship with financial performance $(\mathrm{p}>0.05)$.

\section{Conclusion and Recommendations}

SACCOs have adopted financial engineering practices: product engineering, process engineering and financial solutions engineering in their operations. Financial engineering has an influence on financial performance of SACCOs. Specifically, adoption of process engineering practices can significantly improve the financial performance. As such, SACCOs should automate its operations, adopt paperless services, use mobile banking services platform, use electronic funds transfer and install ATMs. The findings are consistent with the research by Ouma, Omagwa and Ngaba (2018) who established that SACCOs adopt financial engineering and innovation practices to improve their performance. The amount of loans also affect the financial performance positively. Therefore, SACCOs should increase its loans but with caution so as to avoid non - performing loans which can affect its performance.

This study recommends that management of SACCOs should explore mechanisms for enhancing the use of process re-engineering particularly to old processes and products. This will not only revitalize their products and processes, but also act as a form of organizational branding that is essential for performance. There is also need to have the firms enhance customer care delivery channels in a manner that is 
consistent, less costly, and more agile. This can only be enhanced by use of process engineering within organizations. The firms should also change their management systems in order to improve service delivery to their customers. The firms should also undertake organization restructuring and external relation in order to reduce their operation costs and improve their financial performance.

\section{References}

[1] Abir, M., \& Chokri, M. (2010). Is financial innovation influenced by financial liberalization? Evidence from the Tunisian banking industry. Banks and Bank Systems, 5(3), $97-111$.

[2] Al-Jilan, M.H. (2016). The role of Islamic financial engineering in minimizing global financial crises results on Islamic banking. Research Journal of Finance and Accounting, 7, (2), 42-54.

[3] Cherotich, K. M., Sang, W., Shisia, A., \& Mutung'u, C. (2015). Financial innovations and performance of commercial banks in Kenya. International Journal of Economics, Commerce and Management; III, 5, 1242 - 1265.

[4] Ebrahim, M.S., Hussain, S. (2010). Financial development and asset valuation: the special case of real estate. Journal of Banking and Finance, 34, 150-162.

[5] Ibraheem, H.A. (2013). Mechanisms of financial engineering as new alternatives. Journal of Arts Science \& Commerce, IV, 3, 21 - 39.

[6] Iman, M. M. A., Sharul, E.B.J., \& Azam, A.K.A (2019). The relationship between financial engineering and financial performance in Iraq commercial banks. Journal of Advanced Research in Dynamical \& Control Systems, 2, 3346.

[7] Kiragu, D. N. (2015). Influence of financial innovations on financial performance of savings and credit co-operative societies in Nyeri County, Kenya. Nairobi: University of Nairobi.

[8] Klein, M.W., Olivei, G.P. (2008). Capital account liberalization, financial depth, and economic growth. Journal of International Money and Finance, 27, 861-875.

[9] Milnes, A. (2006). What is in it for us? Network effects and bank payment innovation. Journal of Banking and Finance, 30, 1613-1630.

[10] Mutuku, B. M. (2014). The Relationship Between Financial Innovation and Efficiency of Saccos in Kenya, Unpublished Doctoral dissertation. Nairobi: University of Nairobi.

[11] Neeraj N. (2011). Role of financial innovation in reengineering business: An Overview, 28-30.

[12] Ngure, F. K., Kimani, E. M. \& Kariuki, S. (2017). Product innovations and financial performance of savings and credit co-operatives societies in Kirinyaga County, Kenya. International Academic Journal of Human Resource and Business Administration, 2(3), 166-178.

[13] Oksana, R. J. \& Alexander, K. (2013). The diffusion of banking innovations: bank cards on Russian market. Innovative Marketing, 9(3) 
[14] Omisore. I., Yusuf .M \& Nwufo C.I, (2012). The modern portfolio theory as an investment decision tool. Journal of Accounting and Taxation, 4(2), 19-28.

[15] Osuoha, J. (2013). Commodity Trading and Futures. Lagos: Emmaesth Printing \& Publishing.

[16] Ouma, A.A., Job Omagwa, J., \& Ngaba, D. (2018). Financial innovations and performance of deposit taking SACCOS in Nairobi city county, Kenya. International Journal of Economics, Business and Management Research; 2, 02.

[17] Sayyed, I. (2015). The effects and implications of financial engineering in the corporate world - a review. International Journal of Engineering Research and Development; 11, 12, 76-90.

[18] Swailem, S. (2000). Financial engineering industry: Looks at the Islamic approach. Research Center, 5. 